УДК 343.72 (477)

DOI https://doi.org/10.32849/2663-5313/2020.4.50

\title{
Володимир Кондратов,
}

здобувач Донецького юридичного інституту

Міністерства внутрішніх справ України

\section{СУБ'СКТ ЗЛОЧИНІВ, ПОВ' ЯЗАНИХ ІЗ ПОСЯГАННЯМ НА ЖИТТЯ ТА ЗДОРОВ'Я ПРАЦІВНИКІВ ПРАВООХОРОННИХ ОРГАНІВ}

Досліджено суб'єкт злочину як один із чотирьох обов'язкових елементів складу злочину. Проаналізовано обов'язкові та факультативні ознаки суб'єкта злочинів, передбачених статтями 345, 348 та 349 КК України. Розглянуто проблемні питання законодавчої регламентації суб'єкта погрози або насильства щодо державного чи громадського діяча. Визначено та проаналізовано основні критерії суб'єкта злочину. Запропоновано шляхи розв'язання окремих дискусійних положень чинного законодавства.

Проведено ретроспективний аналіз становлення законодавчої конструкції суб'єкта злочину та формування його ознак.

Констатовано, що знижений вік кримінальної відповідальності законодавець передбачив за злочини, пов'язані з посяганням на життя та здоров'я прачівників правоохоронних органів - ч. 2 та 3 cm. 345, ст.ст. 348 та 349 КК Украӥни. Це, відповідно, умисне заподіяння прачівникові правоохоронного органу чи його близьким родичам побоїв, легких або середньої тяжкості тілесних ушкоджень у зв'язку з виконанням иим пращівником службових обов'язків; умисне заподіяння працівникові правоохоронного органу або його близьким родичам тяжкого тілесного ушкодження у зв'язку з виконанням чим прачівником службових обов'язків; посягання на життя працівника правоохоронного органу; захоплення представника влади або працівника правоохоронного органу як заручника.

Звертається увага на недосконалість редакиї ст. 22 КК України та непослідовність законодавия у встановленні віку, з якого може наставати кримінальна відповідальність. Запропоновано внести зміни до ч. $2 \mathrm{~cm} .22$ КК України, передбачивщи настання кримінальної відповідальності з чотирнадияти років за погрозу вбивством, насильством або знищенням чи пошкодженням майна щодо працівника правоохоронного органу, а також щодо його близьких родичів у зв'язку з виконанням цим прачівником службових обов'язків.

Зроблено висновок про актуальність подальшої грунтовної розробки питання суб'єкта цих злочинів, зокрема, стосовно можливості зниження віку кримінальної відповідальності.

Ключові слова: злочин, суб'єкт, осудність, вік, працівник правоохоронного органу.

Постановка проблеми. Наукове обгрунтування встановлення ознак будь-якого злочину є доволі складним завданням. Це стосується й чіткого встановлення ознак суб'єкта кримінальної відповідальності за погрозу або насильство щодо працівника правоохоронного органу.

Проблемі суб’єкта складів злочинів приділяли увагу такі вчені, як: В. В. Сташис, Ю. В. Александров, А. В. Агафонов та інші. Проте системного дослідження суб'єкта злочинів, пов'язаних із посяганням на життя та здоров'я працівника правоохоронного органу, не проводилось.

Метою статті є аналіз проблемних питань законодавчої регламентації суб'єкта злочинів, пов'язаних з посяганням на життя та здоров'я працівників правоохоронних органів.
Виклад основного матеріалу. Поняття суб'єкта злочину передбачає дослідження широкого кола питань, що, з одного боку, встановлюють правові ознаки, які характеризують його відповідно до положень кримінального права, та, з іншого боку, розкривають соціально-політичну та моральну сутність злочинця [1, с. 65].

УВ КК України 2001 р. інститут суб'єкта злочину отримав своє законодавче закріплення в ст. ст. 18-22 КК України, де вказано ознаки суб'єкта злочину - осудність та вік, крім того, міститься вказівка на те, що суб'єктом злочину може бути тільки фізична особа.

Відповідно до ч. 1 ст. 18 КК України, суб'єктом злочину є фізична осудна особа, яка вчинила злочин, у віці, з якого, згідно з кримінальним законом, може наставати кримінальна відповідальність. Це законодавче 
визначення охоплює ознаки суб'єкта злочину, які традиційно прийнято називати загальними: 1) особа має бути фізичною; 2) особа має бути осудною; 3) особа має досягти встановленого у законі віку.

Відсутність будь-якої із зазначених ознак свідчить про відсутність ознак складу злочину і застосування кримінальної відповідальності. Суб'єкт злочину є однією з чотирьох обов'язкових ознак складу злочину Разом із тим А.Н. Трайнін виступав проти визнання суб'єкта злочину в системі елементів складу злочину, мотивуючи дану позицію тим, що людина не може бути елементом вчиненого нею діяння [2, с. 191]. У зв'язку з цим Н. С. Лейкіна писала, що включення осудності, а також віку до складу злочину як найбільш важливих ознак суб'єкта являє собою не перетворення злочинця в елемент вчиненого ним суспільно-небезпечного діяння а в спробу найбільш всебічно пояснити склад злочину. Поняття суб'єкта злочину означає передусім сукупність ознак, на підставі яких фізична особа, яка вчинила суспільно небезпечне діяння, підлягає кримінальній відповідальності. Такими постійними і загальними ознаками є осудність і досягнення особою певного віку [3, с. 37].

У теорії кримінального права зазначається, що поряд із загальним суб'єктом існуе і спеціальний суб'єкт злочину, але єдиного поняття змісту цього інституту немає.

Одні вчені спеціальними суб'єктами визначають осіб, які не тільки мають загальні властивості всіх суб'єктів злочину (осудність та вік), але й характеризуються додатково особливими, лише їм властивими якостями $[4$, с. 138]. У цьому визначенні головний акцент робиться на різниці загального та спеціального суб'єкта злочину шляхом вказівки на додаткові ознаки; хоча вони не називалися. Інші науковці вважають, що спеціальним суб'єктом є особа, що має певні особливості, які передбачені в диспозиції відповідної норми Кримінального кодексу [5, с. 8]. Третя група юристів вважає, що спеціальним суб'єктом є особа, яка, крім необхідних ознак суб'єкта (осудність і вік), має ще й особливі додаткові ознаки, які обмежують можливість притягнення до кримінальної відповідальності інших осіб за вчинений злочин [6, с. 82].

Слід погодитися з думкою В. Я. Тація, який вважає, що ознаки спеціального суб'єкта злочину певною мірою є обмежувальними, тому що вони визначають, що певний злочин може вчинити не будь-яка особа, а лише та, яка наділена виключними ознаками [7, c. 161].

Тривалі дискусії в юридичній літературі та відсутність загальновизнаного змісту поняття «спеціальний суб'єкт злочину» сприяли закріпленню (вперше) поняття спеціального суб'єкта злочину у чинному Кримінальному кодексі України, хоча відкритим залишилося питання про ознаки спеціального суб'єкта, що, з нашого погляду, зумовлено неможливістю в Загальній частині Кримінального кодексу України передбачити вичерпний перелік таких ознак [8, с. 57].

Ч. 2 ст. 18 КК України визначає, що спеціальним суб'єктом злочину є фізична осудна особа, що вчинила у віці, з якого може наставати кримінальна відповідальність, злочин, суб'єктом якого може бути лише певна особа.

Сучасне кримінальне право традиційно визнає суб'єктом злочину лише фізичну особу, тобто людину. У Кримінальному кодексі України 1960 р. таке положення випливало з тексту ст. 4 та 5, згідно 3 якими кримінальна відповідальність могла наставати лише щодо громадян України, іноземних громадян, а також осіб без громадянства. У чинному Кримінальному кодексі України законодавець прямо визначив згадану ознаку суб'єкта злочину.

Закон визначає, що суб'єктами злочину можуть бути громадяни України, іноземні громадяни, що не користуються правом особистої недоторканності і дипломатичного імунітету, а також особи без громадянства (ст. ст. 6-8 КК України). Юридичні особи не можуть бути суб'єктом злочину, інакше буде порушений принцип персональної відповідальності за вчинене діяння.

У літературі правильно відзначається, що реальна можливість передбачення особою наслідків своєї діяльності означає, зокрема, що особа мала достатні знання у відповідній галузі, досвід, накопичений у результаті попередньої роботи тощо. На ці можливості впливають зорові, слухові й інші рецептори індивіда, рівень його темпераменту. Будь-яка 3 цих якостей залежить від багатьох обставин і водночас більшою чи меншою мірою визначається віком особи. Вік - найбільш універсальний, хоча і не абсолютний критерій досягнення (недосягнення) особою такого розвитку, за якого вона стає здатною усвідомлювати свої дії і керувати ними.

Осудність - передбачена законом обставина, що є фіксованим показником достатніх в особи здібностей для усвідомлення своїх дій (бездіяльності) і керування ними під час вчинення злочину, що є необхідною умовою наявності суб'єкта злочину та його можливості зазнавати заходів кримінально-правового впливу [9, с. 21].

Питання про осудність особи виникає в нашому дослідженні тільки у зв'язку 3 вчиненням нею злочинів, передбачених 
ст.ст. 345 та 348 КК України, або іншого злочину. Саме щодо них необхідно з'ясувати, чи здатна особа правильно оцінювати суспільно небезпечний характер вчиненого діяння і керувати своїми діями. Стан осудності є типовим станом психіки людини i, як правило, характерний для більшості людей. Тому на практиці питання про встановлення осудності виникає тільки в тому разі, коли злочин виявлявся в діях, що суперечать здоровому глузду і викликають сумнів щодо нормального психічного стану суб'єкта.

Особу, що перебувала у момент вчинення злочину у стані неосудності, не може бути визнано суб’єктом злочину і, відповідно, не може бути притягнуто до кримінальної відповідальності. Якщо осудна особа підлягає за вчинений нею злочин покаранню, то неосудна не може бути засуджена - за вчинення суспільно небезпечних діянь до таких осіб застосовуються примусові заходи медичного характеру.

Чинний Кримінальний кодекс України, на відміну від Кодексу 1960 р., не лише вживає поняття «осудність», а й розкриває його зміст. У ч. 1 ст. 19 КК України визначено, що осудною визнається особа, яка під час вчинення злочину могла усвідомлювати свої дії (бездіяльність) і керувати ними.

Для встановлення неосудності особи використовується змішана формула з урахуванням двох критеріїв:

1) медичний критерій визначає всі можливі психічні хвороби, дає узагальнену характеристику всіх можливих психічних аномалій (хронічне психічне захворювання; тимчасовий розлад психічної діяльності; недоумство; інший хворобливий стан психіки) і є лише можливим джерелом неосудності;

2) юридичний критерій встановлює межі медичного критерію, визначає межі між осудністю і неосудністю та складається з двох ознак: а) інтелектуальна ознака виражена в законі словами «особа не могла усвідомлювати свої дії (бездіяльність)»; б) вольова ознака - «особа не могла керувати ними» $[10$, с. 7$]$.

Наявність одного медичного чи одного юридичного критерію не дає підстави для визнання особи неосудною; для цього необхідна сукупність цих критеріїв. Питання про осудність або неосудність особи вирішується стосовно факту вчинення особою конкретного злочину і лише на момент його вчинення.

Як бачимо, кримінально-правові ознаки суб'єкта злочину включають у себе порівняно невеликий перелік. Сюди належать тільки ті особливості суб'єкта злочину, які мають значення для вирішення питання про притягнення особи до кримінальної відповідальності. Вони пов'язані зі з'ясуванням змісту кримінально-правової норми. Виявлення ознак кри- мінально-правового характеру зумовлено необхідністю встановлення у суспільно небезпечних діях (бездіяльності) особи складу злочину іздійснення процесу правової кваліфікації.

Ознаки, що характеризують суб'єкта, нерозривно пов'язані з усіма іншими елементами складу злочину. Саме своїм суспільно небезпечним діянням (об'єктивна сторона злочину) суб'єкт завдає шкоди об'єкту посягання, діючи при цьому винно (суб'єктивна сторона). Суб'єкт злочину - це не абстрактне юридичне поняття, що існує поза часом і простором, а людина, що живе в суспільстві і вчиняє злочинні дії.

Досягнення визначеного законом віку $€$ необхідною умовою кримінальної відповідальності. На вибір законодавцем оптимального вікового мінімуму, що допускає кримінальну відповідальність, впливає безліч факторів, зумовлених політичними, соціальними й економічними передумовами.

Суть дискусії про мінімальний вік кримінальної відповідальності зумовлена ставленням до самої відповідальності. Якщо кримінальна відповідальність і покарання є тільки карою, то можна говорити про знижений вік кримінальної відповідальності осіб; якщо це засіб захисту суспільства від злочинних посягань - суспільство насамперед повинне виховувати неповнолітніх, а не карати ї. Наша держава пройшла достатній шлях розвитку, щоб визнавати метою покарання не тільки кару, а й виправлення засуджених.

За загальним правилом кримінальній відповідальності підлягають особи, яким до вчинення злочину виповнилося шістнадцять років. Ч. 2 ст. 22 КК України містить вичерпний перелік злочинів, за вчинення яких відповідальності підлягає особа, що досягла до часу вчинення злочину 14-річного віку. Виходячи з тексту ч. 2 ст. 22 КК України, слід зазначити, що знижений вік кримінальної відповідальності законодавець передбачив за такі злочини, пов'язані з посяганням на життя та здоров'я працівників правоохоронних органів, - ч. 2 та 3 ст. 345 , ст.ст. 348 та 349 КК України. Це, відповідно, умисне заподіяння працівникові правоохоронного органу чи його близьким родичам побоїв, легких або середньої тяжкості тілесних ушкоджень у зв'язку з виконанням цим працівником службових обов'язків; умисне заподіяння працівникові правоохоронного органу або його близьким родичам тяжкого тілесного ушкодження у зв'язку з виконанням цим працівником службових обов'язків; посягання на життя працівника правоохоронного органу; захоплення представника влади або працівника правоохоронного органу як заручника. 
Маємо відзначити недосконалість ст. 22 КК України та непослідовність законодавця у встановленні віку, з якого може наставати кримінальна відповідальність. Зокрема, це стосується ч. 1 ст. 345 КК України. Даний склад злочину не включено до ч. 2 ст. 22 КК України, тоді як, скажімо, вимагання - злочин, передбачений ст. 189 Кодексу, який з об'єктивної сторони полягає у вимозі передачі чужого майна чи права на майно або вчиненні будь-яких дій майнового характеру з погрозою насильства над потерпілим чи його близькими родичами, обмеженні прав, свобод або законних інтересів цих осіб, пошкодженні чи знищенні їхнього майна або майна, що перебуває в їхньому віданні чи під охороною, або розголошенні відомостей, які потерпілий чи його близькі родичі бажають зберегти в таємниці, - визнається таким, за який особа може нести кримінальну відповідальність із чотирнадцятирічного віку.

\section{Висновки}

Отже, особа у віці від чотирнадцяти до шістнадцяти років здатна і повинна усвідомлювати весь ступінь суспільної небезпеки вчинюваного нею діяння, передбаченого ст. 189 КК України або ч. ч. 2, 3 ст. 345 Кодексу та, відповідно, мотиви, яким вона керується і мету, якої прагне. На нашу думку мотив у злочинах, передбачених частинами 1, 2, 3 ст. 345 КК України, $є$ ідентичним. Спосіб вчинення злочину, передбаченого ч. 1 ст. 345 Кодексу, майже повністю збігається з аналогічною ознакою об'єктивної сторони складу злочину, передбаченого ст. 189 КК України - вимагання.

Таким чином пропонуємо внести зміни до ч. 2 ст. 22 КК України, передбачивши настання кримінальної відповідальності 3 14-ти річного віку за вчинення злочину, передбаченого ч. 1 ст. 345 КК України.

\section{Список використаних джерел:}

1. Уголовное право УССР: Общая часть : учебник / под ред. проф. В. В. Сташиса и доц. А. Ш. Якупова. Київ : Вища школа, 1984. 384 с.

2. Трайнин А.Н. Общее учение о составе преступления. Москва : Государственное издательство юридической литературы, 1957. 363 с.

3. Лейкина Н.С. Личность преступника и уголовная ответственность. Ленинград : Издательство Ленинградского университета, 1968. 128 с.

4. Орлов В.С. Субъект преступления по советскому уголовному праву. Москва : Госиздат юрид. лит., 1958. 258 с.

5. Владимиров В.А., Левицкий Г.А. Субъект преступления по советскому уголовному праву: Лекции. Москва : Высш. шк. МООП РСФСР, $1964.59 \mathrm{c}$

6. Орымбаев Р. Специальный субъект преступления. Алма-Ата: Наука, 1977. 151 с.

7. Уголовное право Украины: Общая часть : учебник / под ред.: М.И. Бажанова, В.В. Сташиса, В.Я. Тация. Київ : Юринком Интер, 2003. 512 с.

8. Гончар T.О. Неповнолітній як суб'єкт відповідальності за кримінальним правом України : дис. ... канд. юрид. наук: 12.00.08. Одеса, 2004. 211 с.

9. Васильєв А.А. Проблеми осудності у кримінальному праві : дис. ... канд. юрид. наук: 12.00.08. Харків, 2005. 221 с.

10. Назаренко Г. В. Невменяемость: Уголовнорелевантные психические состояния. СПб.: Издательство «Юридический центр Пресс», 2002. 207 с.

11. Лень В. В. Кримінально-правові проблеми визначення осудності злочинця : автореф. дис. ... канд. юрид. наук: 12.00 .08 . Запоріжжя, 2003. $19 \mathrm{c}$

The subject of crime is investigated as one of the four mandatory elements of the crime. The obligatory and optional features of the subject of crimes provided for in Articles 345, 348 and 349 of the Criminal Code of Ukraine are analyzed. The problematic issues of legislative regulation of the subject of threat or violence against a state or public figure are considered. The main criteria of the subject of crime are identified and analyzed. Ways of solving some debatable provisions of the current legislation are proposed.

A retrospective analysis of the formation of the legislative structure of the subject of crime and the formation of its signs. It has been ascertained that the legislator has foreseen a reduced age of criminal responsibility for such crimes related to the encroachment on the life and health of law enforcement officials - part 2 and 3 of art. 345, Article 348 and 349 of the Criminal Code of Ukraine. This, respectively, is the deliberate infliction of beatings, light or moderate bodily harm to an employee of a law enforcement body or his close relatives in connection with the performance of official duties by that employee; intentional infliction of serious bodily harm to an employee of a law enforcement body or his close relatives in connection with the performance of official duties by this employee; encroachment on the life of a law enforcement officer; capture of a government official or law enforcement official as a hostage.

Attention is drawn to the imperfection of the wording of Art. 22 of the Criminal Code of Ukraine and the inconsistency of the legislator in determining the age from which criminal liability can occur. It is proposed to amend Part 2 of Art. 22 of the Criminal Code of Ukraine with the prediction of the onset of criminal liability from the age of fourteen for the threat of murder, violence or destruction or damage to property against a law enforcement officer, as well as against his close relatives in connection with the employee's official duties.

The conclusion is drawn on the relevance of the further thorough development of the subject of these crimes, including the possibility of reducing the age of criminal responsibility.

Key words: crime, subject, sanity, age, law enforcement officer. 